\title{
Effect of some organic fertilizers on growth, yield and quality of tomato (Solanum lycopersicum)
}

\section{Fatimah Obaid Saeed Ali Kalbani, Mohammed A. Salem*, Abdul J. Cheruth, Shyam S. Kurup, A. Senthilkumar}

Department of Aridland Agriculture, Faculty of Food and Agriculture, PO Box No. 15551, United Arab Emirates University, Al Ain, UAE

*Corresponding E-mail: mohammed.s@uaeu.ac.ae

\begin{abstract}
Keywords: Organic fertilizers; tomato; growth analysis; fruit yield; sensory evaluation
\end{abstract}
\begin{abstract}
In the present study, a field experiment was conducted to study the effect of some organic fertilizers on four varieties of tomato viz., Sadia F1, Isabella F1, Lelord and Sun cherry for its growth, yield and fruits sensory. A total of 64 plots were prepared with the dimension of $3 \mathrm{~m}^{2} \times 4 \mathrm{~m}^{2}$ and each plot was applied with recommended doses of organic fertilizers. The results on the growth parameters of the studied tomato varieties showed that the chicken manure had the significant effect on plant height and root length of Isabella F1, leaf area of sun cherry, root fresh and dry weight and of Lelord, leaves fresh and dry weight of Sadia F1. Whereas, shoot fresh and dry weight of Isabella tomato variety was increased when treated with mixed manure. Agro fish pellet treatment had increased the stem diameter of Isabella F1 significantly. The number of flowers and fruits of sun cherry tomato variety were increased when treated with agro fish pellet. Agro fish also influenced the fruits number in Sadia F1 and fruit yield of lelord followed by Isabella F1 respectively. The sensory evaluation of the fruits of studied tomato varieties revealed that chicken manure had good result on the overall quality of the fruits of Sadia F1 and Sun cherry. Agro fish pellet and mixed manure has influenced the overall quality of Isabella F1 and Lelord variety tomato fruits.
\end{abstract}

\section{Introduction}

Now a days the rise of food production is the major challenges to meet the food requirements of growing population in agriculture and it will be remain essential in the future due to the pressure of inhabitants. Many factors influence the crop quality in food production and one of the main factors is the fertilization system. Because, soil fertility is one of the major problems limiting crop production [1]. The growth and yield of vegetable crops are mainly depends on the quality and quantity of fertilizers used [2]. So, to increase the soil fertility and yield, inorganic/chemical fertilizers are often used. Frequent and high rate uses of inorganic fertilizer have been associated with some environmental pollution, alteration in soil textures and physical property of the soil. Moreover, the nutritional value of the crops will be affected seriously by the continuous use of synthetic fertilizer [3] also inorganic fertilizers will increase the cost of crop production. Now, throughout the world, the demand for organic foods is increased among the consumers that are good for health and the environment. Furthermore, consumers often look upon the taste of organic products and it should be healthier one than the conventional one [4]. Apart from the release of nutrient is slow manner, the application of organic fertilizers, which are made from animal excreta or other agricultural wastes is usually used to improve the structure and stability of the soil and in addition to enhancing the yield and quality of the crop plants $[2,5,6]$

Tomato (Lycopersicon esculentum Mill.) is one of the most important vegetables worldwide. As it is a relatively short duration crop and gives a high yield, it is economically attractive and the area under cultivation is increasing daily [7] Moreover, tomatoes contribute to a healthy, wellbalanced diet and having rich in minerals, vitamins, essential amino acids, sugars and dietary fibres. Tomato contains much vitamin $\mathrm{B}$ and $\mathrm{C}$, iron and phosphorus. Tomato fruits are consumed fresh in salads or cooked in sauces, soup and meat or fish dishes. They can be processed into purées, juices and ketchup. Canned and dried tomatoes are economically important processed products. So, the 
aim of this study is to evaluate the effects different of organic fertilizers (viz. cow manure, mixed manure (Chicken+ cow), Chicken manure pellet and agro fish pellet) on four different varieties of tomato by studying the growth and yield parameters and sensory evaluation of the fruits.

\section{Materials and Methods}

\section{Cultivar selection and Seed materials}

Tomato varieties (viz., Sadia F1, Isabella F1, Lelord and Sun cherry) were selected based on available in the markets of the United Arab Emirates (UAE), as they are more varieties used by farmers in the state most types of conventional and organic crops, and others.

\section{Study Site}

The experiment was conducted in greenhouse during 2011 - 2012 at Al- Foah Experimental Farm, College of Food and Agriculture, United Arab Emirates University, Al Ain.

\section{Experimental Design}

The experimental was set in factorial experimental with a randomized block design, $4 \mathrm{x} 4$ factorial experiments with 3 replications. The first factor was organic (Cow Manure (AL BAQARA) Chicken+ cow (AL MROOG) - Chicken manure pellet - Agro fish pellet) and the second factor was varieties of tomatoes (Sadia F1, Isabella F1, Lelord and Suncherry). The nutrient profile of studied organic fertilizer is given in Table No.1.

Seeds were sown and uniform seedling were transplanted to the greenhouse. The total number of elementary plots was 64 , Plot dimension was $3 \mathrm{~m} 2 \times 4 \mathrm{~m} 2$, and each plot received only the recommended doses of organic fertilizers:

1- Cow Manure (AL BAQARA) at the rate of $18 \mathrm{~kg}$ for plot

2- Chicken+ cow (AL MROOG) at the rate of $318 \mathrm{~kg}$ for plot.

3- Chicken manure pellet at the rate of $18 \mathrm{~kg}$ for plot.

4 - Agro fish pellet at the rate $18 \mathrm{~kg}$ for plot.

It also has been added to organic fertilizers mixed with soil within the unit assigned to each pilot fertilizers and by random distribution of transactions within the sector during the preparation of the soil before the date of Agriculture. The Organic material liquid humic acid has been used bribes to shoot five times during the growing season Spatter the first month after planting seedlings in the greenhouse and between each workshop and another two weeks, It was added by five times during the growing season added the first month after planting seedlings in the greenhouse at a rate of 2 liters per unit experimental and nearly 3 gallons for the experience.

\section{Measurement of plant growth parameters}

Vegetative growth of the studied tomato plants (viz., plant height, stem diameter, number of branches and leaves per plant, leaf area $\left(\mathrm{cm}^{2}\right)$ and root length as well as fresh and dry weights of tomato shoots and roots) were evaluated. The plant height was measured from the soil level to the tip of the shoot and expressed in $\mathrm{cm}$. The plant root length was measured from nodal initiation of the shoot to the tip of longest root and expressed in $\mathrm{cm}$. After washing the plants in the tap water, fresh weight of the root, shoot and leaves were determined by using an electronic balance and the values were expressed in grams. After taking fresh weight, the plants were dried at $60{ }^{\circ} \mathrm{C}$ in hot air oven for 24 hours. After drying, the weight was measured and the values were expressed in grams.

\section{Measurement of yield parameters}

Tomato fruits were harvested twice weekly at the pink to red-ripe stage. Weekly yields were determined by pooling the two weekly harvests. Measured yield parameters included number of flower per plant, number of fruits per plant and yield per plant. 


\section{Sensory Evaluation}

The sensory quality was evaluated, Includes (Appearance, Firmness, Consistency, Color, Sweetness, Sourness, Bitterness, Juiciness and Overall Quality) by a panel of fifty testers (fourty three females and siven males, aged 21-49 years). Sixteen types of tomato were presented to 50 panelists and randomly coded sample, the 50 panelists were asked to rate the different tomato's presented to them on a 9 point hedonic scale with the rating of: $9=$ like extremely, $8=$ like very much, $7=$ like moderately, $6=$ like slightly, $5=$ neither like nor dislike, $4=$ dislike slightly, $3=$ dislike moderately, $2=$ dislike very much, $1=$ dislike extremely.

\section{Statistical analysis}

The results were evaluated by analysis of variance (ANOVA) and Duncan's Multiple Range Test (DMRT) procedures of the Statistical Analysis System (SAS, 2011). Means comparisons between treatments were performed by the least significant difference (LSD) test. Statistical significance was indicated at a probability level of $\mathrm{P}>0.05$.

\section{Results and Discussion}

In the present study, the organic fertilizers had the significant influence on the plant growth, yield and quality of studied tomato verities and the results are presented in Figure Nos. 1 and 2 and Table Nos. 2-5. Figure 1a showed the significant differences between effects of fertilizers on tomato height. The results revealed that chicken manure had the best effect and the mixed manure (chicken + cow) had the least effect on plant height. Isabella F1 tomato variety responded the most to all types of fertilizers as compared with other varieties.

The result of effect of organic fertilizer on stem diameter of the studied tomato plants is given in Fig. 1b. Agro fish pellet had the best effect on stem diameter and the mixed manure (chicken + cow) had the least effect on stem diameter. Isabella F1 tomato variety responded the most to all types of fertilizers as compared with other varieties. Even though chicken manure had slight influence on number of branches of sun cherry (Fig. 1c), there was no significant difference has been observed on this parameter. Isabella F1 and sun cherry tomato varieties had similar response to the organic fertilizer on leaf area index (Fig 1d). Treatment with chicken manure increases the leaf area of sun cherry significantly. Chicken manure showed significant effect on root length of Isabella F1 (Fig. 1e). Moreover, agro fish pellet showed the least effect on root length of studied tomato varieties when compared to other organic fertilizers. The effect of organic fertilizers on fresh shoot weight of studied tomato verities is given in Fig. f. Mixed manure showed significant differences on fresh shoots weight of Isabella F1 tomato variety. Chicken manure increased the root fresh weight of Lelord tomato variety significantly (Fig. 1g) and the mixed manure had the least effect on fresh roots weight of sun cherry. The effect of organic fertilizer on the fresh leaves weight of studied tomato varieties is given in Fig. 1h. Agro fish pellet and chicken manure showed good effect on the fresh leaves weight of Sadia F1 tomato variety. Sun cherry variety treated with mixed manure sowed the least effect on fresh leaves weight of the plant. Mixed manure followed by agro fish were significantly increased the shoot dry weight of Isabella F1 (Fig. 1i). Whereas, the mixed manure degreased the shoot dry weight of sun cherry. The results of root dry weight of studied tomato varieties treated with various organic fertilizers are presented in Fig. 1j. Chicken manure has increased the root dry weight of Lelord tomato variety significantly. Sun cherry variety treated with mixed manure has decreased the dry weight of roots. Leaves dry weight of Sadia F1 has significantly increased when treated with chicken manure. But, leaves dry weight decreased in the sun cherry tomato variety treated with mixed manure.

The crop response to fertilizer application is affected by nutrient reserve in the soil. Also crops respond more to fertilizer application in soils with very low nutrient content than soils with high nutrient reserve [8,9]. Apart from the release of nutrient elements to the soil, organic fertilizers improve the chemical and physical properties of soil which enhance crop growth and development [10]. According to the experimental results of the present study, chicken manure was the most influential organic manure in plant height, number of branches, root length, shoot weight, root 
weight, dry shoot weight, root weight and dry weight of the leaves, as was the compost mixed had the least influential in the growth stage of the studied tomato varieties. It may be due to the high content of nitrogen present in the chicken manure compared to others. In addition, poultry manure has also been reported to increase soil $\mathrm{pH}[11,12]$, hence the acidic soil of the experimental site which might have caused the unavailability of nutrient elements to the crop was checked by the limiting potential of organic manure. So, during growth phase chicken manure can be applied for best growth of tomatoes plants.

The results of yield parameters of the studied tomato varieties viz. number of flowers, number of fruits and fruit yield are given in Fig 2a-c. The number of flowers and fruits in sun cherry tomato variety were increased when treated with agro fish followed by chicken manure (Fig. 2a). Agro fish manure also influenced the fruits number in Sadia F1 tomato variety (Fig. 2b). Fig. 2c showed the effect of organic fertilizer on the fruit yield of studied tomato varieties. The agro fish pellet had increased the fruit yield of lelord followed by Isabella F1 significantly. The results of the present study also in accordance with the previous studies on tomato $[13,14,15]$, Chinese cabbage [16] (Ye et al. 2004) and grapes [17].

Sensory attributes as sweetness and acidity have been correlated with sugar and acid content $[18,19,20]$, but they are only part of the explanation for flavor and overall acceptance. High drymatter content has also been seen as an indicator for good taste of tomato fruits [20,21] and it can affect the taste positively [22] However, an explanation for the higher drymatter content of these fruits cannot easily be found. Because, dry-matter and sugar contents have been reported to increase under high radiation or nutrient concentration, acids and secondary metabolites that are synthesized during fruit maturation could not be linked to the water and carbon fluxes between the plant and the fruit [21].

Fruits of studied tomato varieties were evaluated for its appearance, firmness, consistency, color, sweetness, sourness, bitterness, juiciness and overall quality through a taste testing panel and the results are presented in Table Nos. 2-5. The results on the mean score for sensory evaluation of the Sadia F1 tomato variety is given in Table No. 2. Mixed manure showed best results on firmness, color and bitterness. But, the best results on consistency, sweetness, sourness and juiciness of the fruits were obtained with the treatment of chicken manure and also the best result on the overall fruit quality of Sadia F1 was obtained with the treatment of chicken manure. Table No. 3 represented the results on the sensory of Isabella F1 tomato variety treated with different organic manure. Fruits obtained from agro fish pellet treated plants showed good results on appearance of fruits, firmness, consistency, color, sweetness, juiciness and the overall quality. The results on the sensory evaluation of the Lelord tomato variety are presented in Table No. 4. Even though cow manure treated fruits showed best results on appearance, sweetness, sourness, bitterness and juiciness, the overall quality of the fruits were good in mixed manure treated fruits. Table No. 5 showed the results of sensory evaluation of sun cherry tomato variety treated with various organic manure. Appearance, firmness, consistency and color of the fruits were good in cow manure treated fruits. Whereas, good result on sweetness, sourness and bitterness of the fruits were observed in chicken manure treated fruits. Furthermore chicken manure treated fruits had the good result on overall quality. The sensory evaluation results of the present study were purely depended on the variety of tomatoes. It has also been confirmed by previous studies. The principal component analyses of the tomato illustrated that the variability of the tomatoes was more influenced by varietal differences than by growing conditions [23].

\section{Conclusion}

The results of sensory evaluation of tomatoes showed that the chicken manure had influence the overall quality of fruits of Sadia F1 and Sun cherry tomato variety. Whereas agro fish pellet and mixed manure influence the overall quality of Isabella F1 and Lelord tomato variety respectively. So, adding chicken manure and agro fish pellet at the stage of flowering and fruit set and also in addition that mixed fertilizer before harvest will increase the quality of the fruits of tomato. 


\section{Acknowledgement}

The authors are gratefully acknowledged the authorities of United Arab Emirates University for providing necessary facilities to carry out the present study.

Table 1. Nutrient Profile of selected Organic Fertilizers

\begin{tabular}{lcccc}
\hline \multirow{2}{*}{ Nutrient Profiles } & \multicolumn{4}{c}{ Name of the Fertilizer } \\
\cline { 2 - 5 } & Cow & Mix & Chicken & Agro fish \\
\hline Organic Matter & $45 \%$ & $45 \%$ & $50 \%$ & $65 \%$ \\
PH & 7 & 6.5 & 7 & 6 \\
EC & $10 \mathrm{~m} . \mathrm{mhos} / \mathrm{cm} 3$ & $10 \mathrm{~m} . \mathrm{mhos} / \mathrm{cm} 3$ & $9 \mathrm{~m} . \mathrm{mhos} / \mathrm{cm} 3$ & $10 \mathrm{~m} . \mathrm{mhos} / \mathrm{cm} 3$ \\
Moisture & $20 \%$ & $20 \%$ & $15 \%$ & $12 \%$ \\
CN Ratio & $20: 1$ & $15: 1$ & $17: 1$ & $10: 1$ \\
Sodium Chloride & $0.75 \%$ & $1 \%$ & $1 \%$ & $1.5 \%$ \\
Total Nitrogen & $1.5 \%$ & $2 \%$ & $2.5 \%$ & $5 \%$ \\
Phosphorus & $1.5 \%$ & $1.5 \%$ & $1 \%$ & $5 \%$ \\
Potassium & $1.5 \%$ & $1.5 \%$ & $2 \%$ & $2.5 \%$ \\
Trace Elements & $1000 \mathrm{PPM}$ & $1000 \mathrm{PPM}$ & $7000 \mathrm{PPM}$ & $1000 \mathrm{PPM}$ \\
\hline
\end{tabular}

Table 2. Mean score for sensory evaluation of the Sadia F1 tomato variety treated with organic manure

\begin{tabular}{lcccc}
\hline \multirow{2}{*}{ Sensory } & \multicolumn{4}{c}{ Name of the Organic Manure } \\
\cline { 2 - 5 } Appearance & Cow manure & Mixed manure & Chicken manure & Agro fish pellet \\
Firmness & $6.920 \pm 1.736^{\mathrm{a}}$ & $7.180 \pm 2.027^{\mathrm{a}, \mathrm{b}}$ & $7.900 \pm 1.809^{\mathrm{a}, \mathrm{b}, \mathrm{c}, \mathrm{d}}$ & $8.200 \pm 0.968^{\mathrm{b}, \mathrm{c} . \mathrm{d}}$ \\
Consistency & $7.000 \pm 1.498^{\mathrm{a}}$ & $8.120 \pm 0.982^{\mathrm{cd}}$ & $7.900 \pm 2.052^{\mathrm{bcd}}$ & $7.940 \pm 0.585^{\mathrm{b}, \mathrm{c.d}}$ \\
Color & $7.620 \pm 0.854^{\mathrm{a}, \mathrm{b}}$ & $7.660 \pm 1.598^{\mathrm{a}, \mathrm{b}}$ & $8.360 \pm 0.920^{\mathrm{b}, \mathrm{c}}$ & $8.200 \pm 0.880^{\mathrm{b}, \mathrm{c}}$ \\
Sweetness & $8.020 \pm 1.220^{\mathrm{b}, \mathrm{c}}$ & $8.160 \pm 1.461^{\mathrm{c}, \mathrm{b}}$ & $8.060 \pm 1.150^{\mathrm{b}, \mathrm{c}}$ & $7.940 \pm 1.150^{\mathrm{b}, \mathrm{c}}$ \\
Sourness & $7.260 \pm 1.191^{\mathrm{a}, \mathrm{b}}$ & $7.240 \pm 1.393^{\mathrm{a}, \mathrm{b}}$ & $7.360 \pm 1.966^{\mathrm{a}}$ & $6.660 \pm 1.520^{\mathrm{a}}$ \\
Bitterness & $7.260 \pm 0.964^{\mathrm{a}, \mathrm{b}}$ & $6.920 \pm 1.626^{\mathrm{a}}$ & $7.580 \pm 1.738^{\mathrm{a}, \mathrm{b}}$ & $7.380 \pm 1.353^{\mathrm{a}, \mathrm{b}}$ \\
Juiciness & $7.800 \pm 1.212^{\mathrm{a}, \mathrm{b}}$ & $7.880 \pm 0.939^{\mathrm{a}, \mathrm{b}}$ & $7.480 \pm 1.446^{\mathrm{a}, \mathrm{b}}$ & $7.000 \pm 1.293^{\mathrm{a}}$ \\
Overall Quality & $8.020 \pm 0.714^{\mathrm{a}, \mathrm{b}, \mathrm{c}}$ & $8.080 \pm 1.209^{\mathrm{b}, \mathrm{c}}$ & $8.140 \pm 0.947^{\mathrm{c}}$ & $7.340 \pm 1.479^{\mathrm{a}, \mathrm{b}, \mathrm{c}}$ \\
\hline
\end{tabular}


Table 3. Mean score for sensory evaluation of the Isabella F1 tomato variety treated with organic manure

\begin{tabular}{lcccl}
\hline \multirow{2}{*}{ Sensory } & \multicolumn{4}{c}{ Name of the Organic Manure } \\
\cline { 2 - 5 } & Cow manure & Mixed manure & Chicken manure & Agro fish pellet \\
\hline Appearance & $7.860 \pm 1.160^{\mathrm{a}, \mathrm{b}, \mathrm{c}, \mathrm{d}}$ & $7.500 \pm 1.740^{\mathrm{a}, \mathrm{b}, \mathrm{c}, \mathrm{d}}$ & $7.420 \pm 1.604^{\mathrm{a}, \mathrm{b}, \mathrm{d}, \mathrm{d}}$ & $8.380 \pm 1.259^{\mathrm{d}}$ \\
Firmness & $7.720 \pm 1.485^{\mathrm{a}, \mathrm{b}, \mathrm{c}, \mathrm{d}}$ & $8.000 \pm 1.069^{\mathrm{b}, \mathrm{c}, \mathrm{d}}$ & $7.440 \pm 1.445^{\mathrm{a}, \mathrm{b}, \mathrm{c}}$ & $8.400 \pm 0.989^{\mathrm{d}}$ \\
Consistency & $8.080 \pm 0.944^{\mathrm{a}, \mathrm{b}, \mathrm{c}}$ & $8.200 \pm 0.808^{\mathrm{b}, \mathrm{c}}$ & $7.860 \pm 1.484^{\mathrm{a}, \mathrm{b}, \mathrm{c}}$ & $8.560 \pm 0.993^{\mathrm{d}}$ \\
Color & $7.660 \pm 1.451^{\mathrm{b}, \mathrm{c}}$ & $7.520 \pm 1.501^{\mathrm{a}, \mathrm{b}}$ & $7.540 \pm 1.358^{\mathrm{a}, \mathrm{b}}$ & $7.900 \pm 1.606^{\mathrm{b}, \mathrm{c}}$ \\
Sweetness & $7.280 \pm 1.565^{\mathrm{a}, \mathrm{b}}$ & $7.120 \pm 1.685^{\mathrm{a}, \mathrm{b}}$ & $7.020 \pm 1.531^{\mathrm{a}, \mathrm{b}}$ & $7.340 \pm 1.756 \mathrm{a}, \mathrm{b}$ \\
Sourness & $7.280 \pm 1.547^{\mathrm{a}, \mathrm{b}}$ & $7.540 \pm 1.459^{\mathrm{a}, \mathrm{b}}$ & $7240 \pm 1.532^{\mathrm{a}, \mathrm{b}}$ & $7.260 \pm 1.549^{\mathrm{a}, \mathrm{b}}$ \\
Bitterness & $7.220 \pm 1.741^{\mathrm{a}, \mathrm{b}}$ & $7.360 \pm 1.723^{\mathrm{a}, \mathrm{b}}$ & $7.600 \pm 1.428^{\mathrm{a,b}}$ & $7.500 \pm 1.151^{\mathrm{a}, \mathrm{b}}$ \\
Juiciness & $7.840 \pm 1.658^{\mathrm{a}, \mathrm{b}}$ & $7.700 \pm 1.446^{\mathrm{a}, \mathrm{b}}$ & $7.400 \pm 2.185^{\mathrm{a}, \mathrm{b}}$ & $8.080 \pm 1.084^{\mathrm{a}, \mathrm{b}}$ \\
Overall Quality & $7.440 \pm 1.197^{\mathrm{a}, \mathrm{b}, \mathrm{c}}$ & $7.100 \pm 1.908^{\mathrm{a}, \mathrm{b}}$ & $7.280 \pm 1.726^{\mathrm{a}, \mathrm{b}, \mathrm{c}}$ & $7.700 \pm 1.568^{\mathrm{a}, \mathrm{b}, \mathrm{c}}$ \\
\hline
\end{tabular}

Table 4. Mean score for sensory evaluation of the Lelord tomato variety treated with organic manure

\begin{tabular}{lcccc}
\hline \multirow{2}{*}{ Sensory } & \multicolumn{4}{c}{ Name of the Organic Manure } \\
\cline { 2 - 5 } & Cow manure & Mixed manure & Chicken manure & Agro fish pellet \\
\hline Appearance & $7.980 \pm 0.0979^{\mathrm{b}, \mathrm{c}, \mathrm{d}}$ & $7.960 \pm 1.564^{\mathrm{b}, \mathrm{c,d}}$ & $7.760 \pm 1.546^{\mathrm{a}, \mathrm{b}, \mathrm{c}, \mathrm{d}}$ & $7.260 \pm 2.058^{\mathrm{a}, \mathrm{b}, \mathrm{c}}$ \\
Firmness & $7.740 \pm 1.242^{\mathrm{a}, \mathrm{b}, \mathrm{c}, \mathrm{d}}$ & $7.840 \pm 0.955^{\mathrm{a}, \mathrm{b}, \mathrm{c}, \mathrm{d}}$ & $7.760 \pm 1.302^{\mathrm{a}, \mathrm{b}, \mathrm{c}, \mathrm{d}}$ & $7.560 \pm 1.692^{\mathrm{a}, \mathrm{b}, \mathrm{c}, \mathrm{d}}$ \\
Consistency & $7.560 \pm 1.416^{\mathrm{a}, \mathrm{b}}$ & $7.700 \pm 1.568^{\mathrm{a}, \mathrm{b}}$ & $7.780 \pm 1.542^{\mathrm{a}, \mathrm{b}, \mathrm{c}}$ & $7.880 \pm 1.423^{\mathrm{a}, \mathrm{b}, \mathrm{c}}$ \\
Color & $7.940 \pm 1.235^{\mathrm{b}, \mathrm{c}}$ & $7.960 \pm 1.211^{\mathrm{b}, \mathrm{c}}$ & $7.540 \pm 1.618^{\mathrm{a}, \mathrm{b}}$ & $6.760 \pm 1.221^{\mathrm{a}}$ \\
Sweetness & $7.680 \pm 1.077^{\mathrm{a}, \mathrm{b}}$ & $7.040 \pm 1.905^{\mathrm{a}, \mathrm{b}}$ & $6.840 \pm 2.093^{\mathrm{a}, \mathrm{b}}$ & $7.100 \pm 1.233^{\mathrm{a}, \mathrm{b}}$ \\
Sourness & $7.860 \pm 1.125^{\mathrm{a}, \mathrm{b}}$ & $7.360 \pm 1.746^{\mathrm{a}, \mathrm{b}}$ & $7.440 \pm 1.739^{\mathrm{a}, \mathrm{b}}$ & $7.340 \pm 1.153^{\mathrm{a}, \mathrm{b}}$ \\
Bitterness & $7.600 \pm 1.442^{\mathrm{a}, \mathrm{b}}$ & $7.420 \pm 1.458^{\mathrm{a}, \mathrm{b}}$ & $7.320 \pm 1.731^{\mathrm{a}, \mathrm{b}}$ & $7.120 \pm 1.52^{\mathrm{a}}$ \\
Juiciness & $8.220 \pm 1.111^{\mathrm{a}, \mathrm{b}}$ & $8.020 \pm 1.115^{\mathrm{a}, \mathrm{b}}$ & $7.320 \pm 2.044^{\mathrm{a}}$ & $7.300 \pm 2.111^{\mathrm{a}}$ \\
Overall Quality & $7.580 \pm 1.196^{\mathrm{a}, \mathrm{b}, \mathrm{c}}$ & $7.600 \pm 1.702^{\mathrm{a}, \mathrm{b}, \mathrm{c}}$ & $7.280 \pm 1.604^{\mathrm{a}, \mathrm{b}, \mathrm{c}}$ & $7.380 \pm 1.783^{\mathrm{a}, \mathrm{b}, \mathrm{c}}$ \\
\hline
\end{tabular}

Table 5. Mean score for sensory evaluation of the Sun cherry tomato variety treated with organic manure

\begin{tabular}{lcccc}
\hline \multirow{2}{*}{ Sensory } & \multicolumn{4}{c}{ Name of the Organic Manure } \\
\cline { 2 - 5 } & Cow manure & Mixed manure & Chicken manure & Agro fish pellet \\
\hline Appearance & $8.380 \pm 0.923^{\mathrm{d}}$ & $6.880 \pm 1.780^{\mathrm{a}}$ & $8.220 \pm 0.953^{\mathrm{c}, \mathrm{d}}$ & $8.280 \pm 1.030^{\mathrm{c}, \mathrm{d}}$ \\
Firmness & $8.320 \pm 0.978^{\mathrm{c}, \mathrm{d}}$ & $7.200 \pm 1.829^{\mathrm{a}, \mathrm{b}}$ & $8.220 \pm 0.815^{\mathrm{c}, \mathrm{d}}$ & $8.180 \pm 0.825^{\mathrm{c}, \mathrm{d}}$ \\
Consistency & $8.540 \pm 0.613^{\mathrm{d}}$ & $7.300 \pm 1.147^{\mathrm{a}}$ & $8.120 \pm 1.042^{\mathrm{b}, \mathrm{c}}$ & $8.360 \pm 0.920^{\mathrm{b}, \mathrm{c}}$ \\
Color & $8.500 \pm 0.505^{\mathrm{c}}$ & $7.560 \pm 1.342^{\mathrm{a}, \mathrm{b}}$ & $8.460 \pm 0.862^{\mathrm{c}}$ & $8.360 \pm 0.851^{\mathrm{b}, \mathrm{c}}$ \\
Sweetness & $7.540 \pm 1.528^{\mathrm{a}, \mathrm{b}}$ & $6.960 \pm 1.937^{\mathrm{a}, \mathrm{b}}$ & $7.840 \pm 1.419^{\mathrm{b}}$ & $7.700 \pm 1.541^{\mathrm{a}, \mathrm{b}}$ \\
Sourness & $7.560 \pm 1.853^{\mathrm{a}, \mathrm{b}}$ & $6.980 \pm 1.953^{\mathrm{a}}$ & $8.060 \pm 0.818^{\mathrm{b}}$ & $7.540 \pm 1.991^{\mathrm{a}, \mathrm{b}}$ \\
Bitterness & $7.160 \pm 1.941^{\mathrm{a}}$ & $6.900 \pm 2.130^{\mathrm{a}}$ & $8.280 \pm 0.904^{\mathrm{b}}$ & $7.380 \pm 2.440^{\mathrm{a}, \mathrm{b}}$ \\
Juiciness & $7.880 \pm 0.895^{\mathrm{a}, \mathrm{b}}$ & $7.560 \pm 1.357^{\mathrm{a}, \mathrm{b}}$ & $8.460 \pm 0.862^{\mathrm{b}}$ & $7.680 \pm 2.161^{\mathrm{a}, \mathrm{b}}$ \\
Overall Quality & $7.500 \pm 1.343^{\mathrm{a}, \mathrm{b}, \mathrm{c}}$ & $7.040 \pm 1.640^{\mathrm{a}}$ & $8.140 \pm 1.049^{\mathrm{c}}$ & $8.020 \pm 1.285^{\mathrm{a}, \mathrm{b}, \mathrm{c}}$ \\
\hline
\end{tabular}



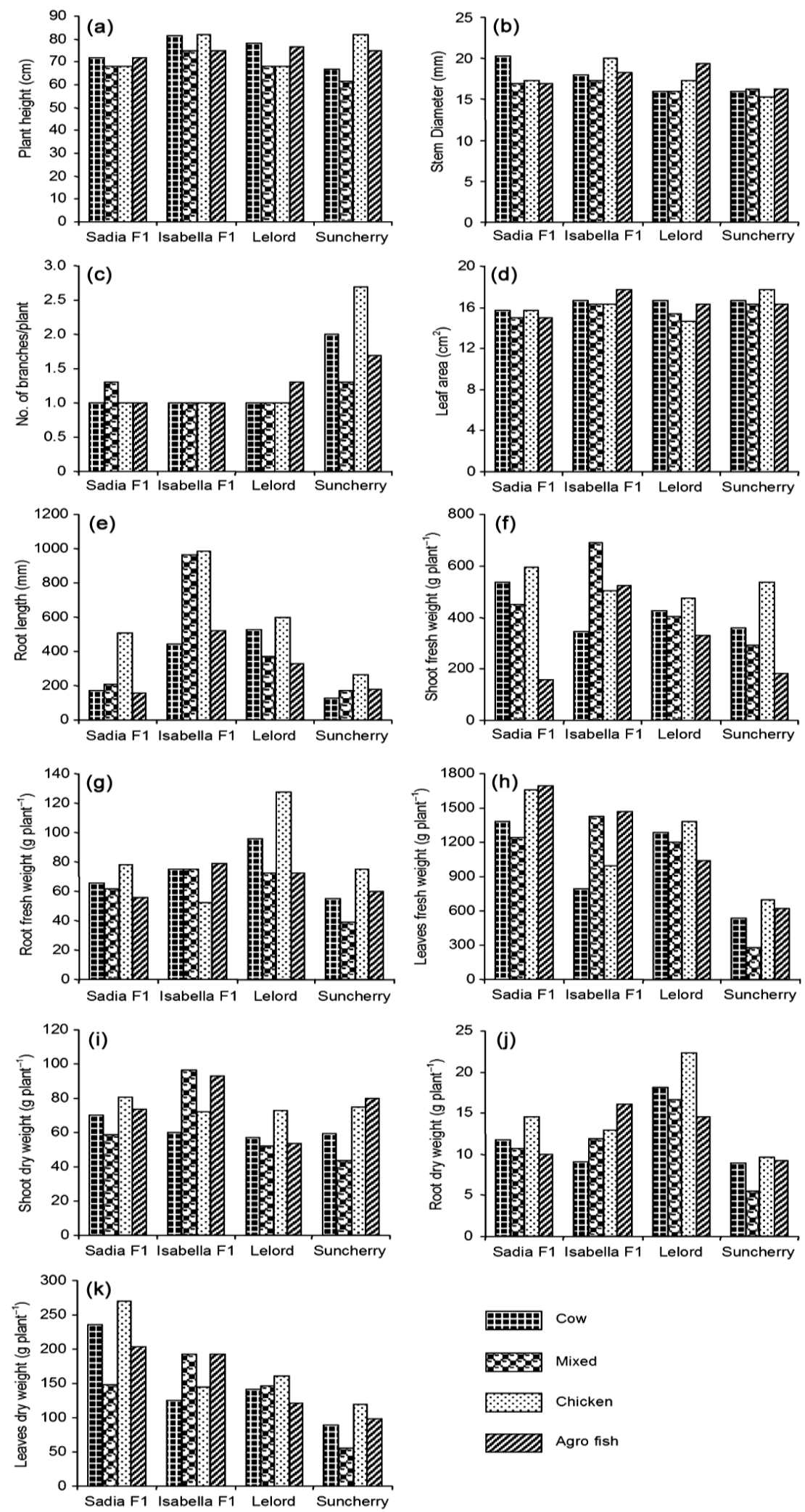

Cow

889 Mixed

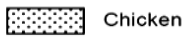

W Agro fish

Figure 1. Effect of organic fertilizers on growth of four varieties of tomato 

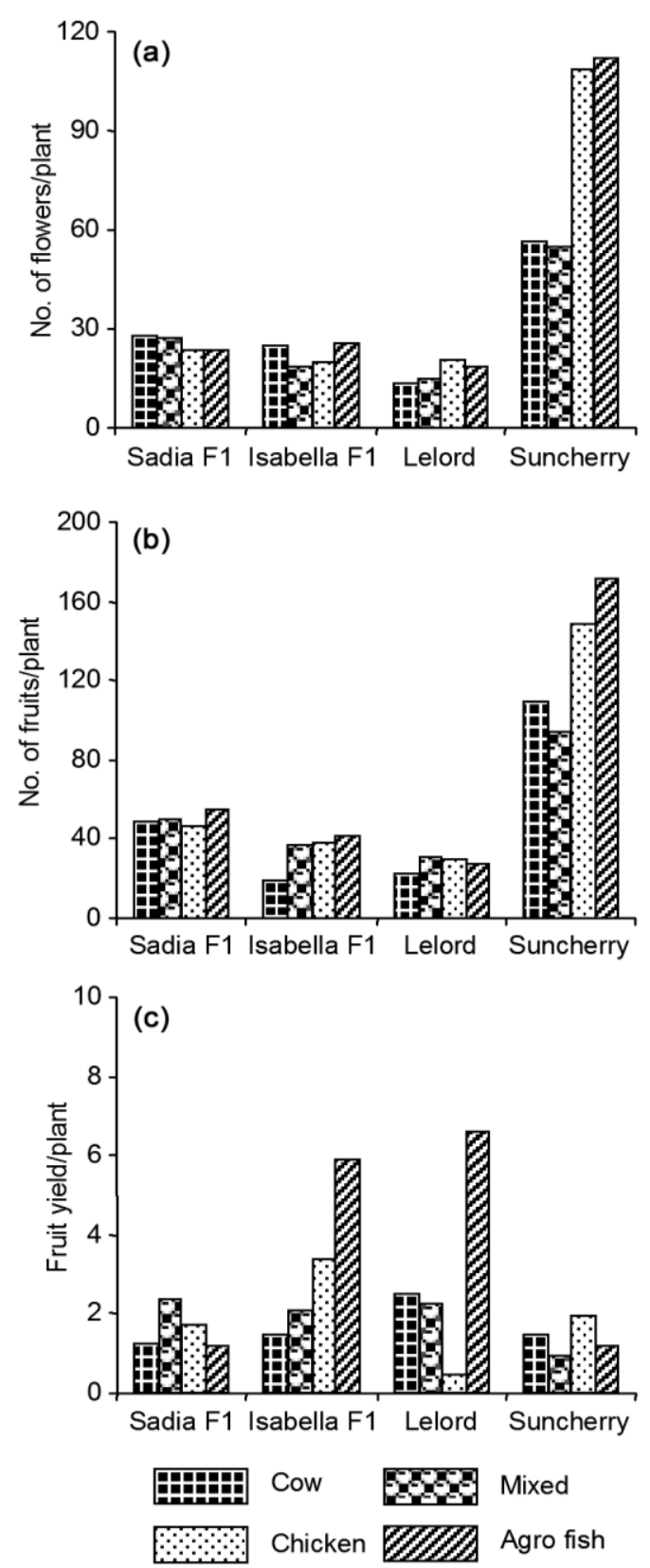

Figure 2. Effect of organic fertilizers on yield of four varieties of tomato

\section{References}

[1] P.E. Ogbonna, Effect of combined application of organic and inorganic fertilizers on fruit yield of egg plant (Solanum melongena). Pro. 42 ${ }^{\text {nd }}$ Annual conf. Agricultural Society of Nigeria (ASN) October $19-23$ pp. 236-250, 2008.

[2] K.H. Chang, R.Y. Wu, K.C. Chuang, T.F. Hsieh, R.S. Chung, Effects of chemical and organic fertilizers on the growth, flower quality and nutrient uptake of Anthurium andreanum, cultivated for cut flower production. Scientia Horticulturae vol. 125, pp. 434-441, 2010.

[3] S. Shimbo, Z.W. Zhang, T. Watanabe, H. Nakatsuka, N. Matsuda-Inoguch, K. Higashikawa, M. Ikeda, Cadmium and lead contents in rice and other cereal products in Japan in 19982000. Science of the Total Environment vol. 281, pp. 165-175, 2001.

[4] L. Ekelund, H. Tjärnemo, Consumer preferences for organic vegetables - The case of Sweden. Acta Horticulturae vol. 655, pp. 121-128, 2004.

[5] M. Tejada, J.L. Gonzalez, Effects of the application of a compost originating from crushed cotton gin residues on wheat yield under dryland conditions. European Journal of Agronomy vol. 19, pp. 357-368, 2003. 
[6] H.A. Marzouka, H.A. Kassem, Improving fruit quality, nutritional value and yield of Zaghloul dates by the application of organic and / or mineral fertilizers. Scientia Horticulturae vol. 127, pp. 249-254, 2011.

[7] S. Naika, J. van Lidt de Jeude, M. de Goffau, M. Hilmi, B. van Dam, Cultivation of tomatoproduction, processing and marketing. Agromisa Foundation and CTA, Wageningen, pp 1-92, 2005.

[8] E.A. Makinde, O.T. Ayoola, M.O. Akande, Effects of organic-mineral fertilizer application on the growth and yield of "egusi" melon (Citrullus vulgaris L.). Australian Journal of Basic and applied sciences vol. 1, no. 1, pp. 15-19, 2007.

[9] A.E. Uko, I.A. Udo, J.O. Shiyam, Optimizing poultry manure rates for two okra (Abelmoschhus esculentus) varieties in a warm wet climate. Journal of Agriculture Biotechnology and Ecology vol. 2, no. 3, pp. 273-285, 2009.

[10] S.N. Dauda, F.A. Ajayi, E. Ndor, Growth and yield of water melon (Citrullus lanatus) as affected by poultry manure application Journal of Agriculture and Social Science vol. 4, pp. 121-124, 2008.

[11] D.J. Udoh, B.A. Ndon, P.E. Asuquo, N.U. Ndaeyo, Crop Production Techniques for the Tropics Concept publication Lagos. Pp.48-216, 2005.

[12] M.S, Ullah, M. S. Islam, M.A. Islam, T. Haque, Effects of organic manure and chemical fertilizers on the yield of brinjal and soil properties. Journal Banladesh Agricultural University. Vol. 6, no. 2, pp. 271-276, 2008.

[13] C.Y.Shi, F.D. Zhang, S.Q. Zhang, H. Li, C.G. Fu, Effects of organic-inorganic compound fertilizers on yield quality and some related physiological characteristics in tomato. Scientia Agricultura Sinica vol. 37, pp1183-1187, 2004.

[14] J.J. Li, G.Y. Zou, D.T Song, Z.T. Xu, Q.P. Sun, B.S. Liu, Influence of compost and chemical fertilizers on tomato yield and quality. Chinese Journal of Soil Science vol. 40, 1330-1332, 2009.

[15] H. Shao,Y.D. Huang, Effect of fermented bio-organic fertilizer on growth and fruit quality of organic tomato. Guizhou Agricultural Science vol. 38, no.5, pp. 63-65, 2010.

[16] J.X. Ye, C.Y. Wu, L.L. Shen, X.M. Zhang, G.C. Zhang, S.Y. Song, Effect of combined application of organic manure and fertilizer on Chinese cabbage yield and quality. Journal of Jilin Agricultural University vol. 26, no. 2, 155-157, 2004.

[17] X.N. Tang, C.Y. Pan, J.H. Zhang, Research of the eco-organic fertilizer and potash fertilizer on grape quality. Journal of Shandong Agricultural University (Natural Science) vol. 39, pp. 570-571, 2008.

[18] T.M.M. Malundo, R.L. Shewfelt, J.W. Scott, Flavor quality of fresh tomato (Lycopersicon esculentum Mill.) as affected by sugar and acid levels. Postharvest Biology and Technology vol.6, pp.103-110, 1995.

[19] D. Ke, M. Boersig, Sensory and chemical analyses of tomato flavor. Hortscience vol. 31, pp. 599-599, 1996.

[20] H. Auerswald, D. Schwarz, C. Kornelson, A. Krumbein, B. Brückner, Sensory analysis, sugar and acid content of tomato at different EC values of the nutrient solution. Scientia Horticulturae vol. 82, pp. 227-242, 1999.

[21] S. Guichard, N. Bertin, C. Leonardi, C. Gary, Tomato fruit quality in relation to water and carbon fluxes. Agronomie vol. 21, pp 385-392, 2001.

[22] G. Hobson, How the tomato losts its taste. New Science vol. 29, pp.46-50, 1988.

[23] L. Johansson, A. Haglund, L. Berglund, P. Lea, E. Risvik, E. Preference for tomatoes, affected by sensory attributes and information about growth conditions, Food Quality and Preference vol. 10, no.4, pp 289-298, 1999. 